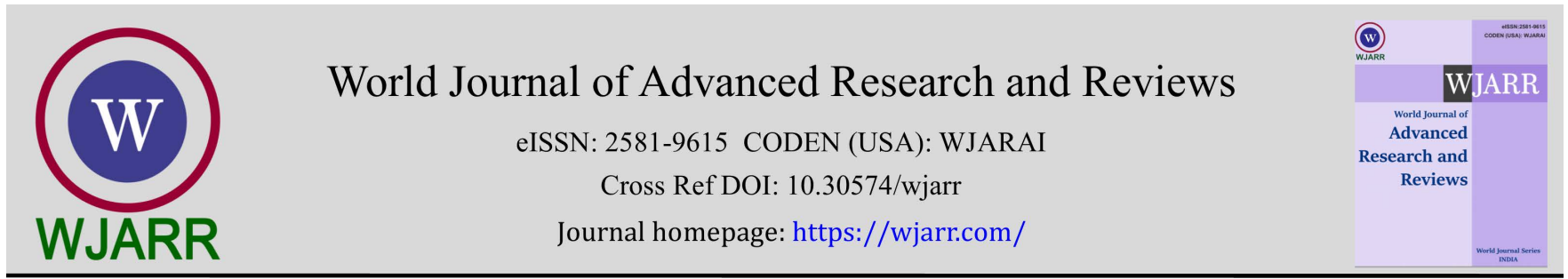

(RESEARCH ARTiClE)

Check for updates

\title{
Comparative analysis of research outputs of academics in Private and Public Universities in South East Nigeria
}

\author{
Ugochi Chinonyerem Mbachu* and Glad Okwuegbunam Unachukwu \\ Department of Educational Management and Policy, Nnamdi Azikiwe University Awka, Nigeria.
}

World Journal of Advanced Research and Reviews, 2022, 13(01), 565-575

Publication history: Received on 07 December 2021; revised on 18 January 2022; accepted on 20 January 2022

Article DOI: https://doi.org/10.30574/wjarr.2022.13.1.0016

\begin{abstract}
This study comparatively analyzed the research output of academics in public and private universities in South-East, Nigeria. Three research questions were formulated for the study and three hypotheses were tested at 0.05 level of significance. Ex post facto design was used for the study. Multistage sampling procedure involving proportionate and disproportionate stratified sampling, and simple random sampling was used to draw a sample size of 1,119 academics (896 from public universities and 1,762 from private universities) from four public and four private universities in two southeastern states (Anambra and Enugu states) of the country. Data were collected using an instrument titled Academic Staff Research Productivity Questionnaire (ASRPQ). The instrument was validated by three experts who are lecturers in Faculty of Education, Nnamdi Azikiwe University, Awka. Cronbach Alpha was used to evaluate the reliability of the instrument, which gave a coefficient of 0.732. Mean was used to answer the research questions while independent samples t-test was used to test the hypotheses at 0.05 level of significance. The results among others reveal that research productivity of academics in both university types is low. Also, academics in public universities were significantly better than those in private universities in more forms of research output. Academics in both university types were found to publish mostly in international journals, and had the least research output in patents and certified inventions. Based on the findings, it was recommended among others that academics be encouraged to explore and utilize other forms of research output for enhanced research productivity.
\end{abstract}

Keywords: Academics; Private Universities; Public Universities; Research; Research Output; South East Nigeria

\section{Introduction}

Research is germane in providing solutions to the problems faced by a nation and its citizens. Globally, the higher education industry recognizes the importance of scientific, qualitative and empirical research and publication of research results. Assessment and ranking of higher educational institutions (HEIs) and their academics are majorly based on their research output. Universities, which are seen as principal knowledge mining institutions and producers of high level skilled manpower for meeting local and international needs, depend heavily on research to meet her obligations. The university through its academic staff carries out research and publishes the outcome of such research as part of the means of providing solution to the problems confronting mankind.

Research, a systematic investigation into a concept, system or problem, aimed at getting useful insights or finding solutions to problems, is an important aspect in the job of academic staff of the university. Scholars [1, 2, 3, 4, 5] and the management of these universities, as evidenced in the distribution of points in appraisal system for academics, have consistently buttressed this fact. How well academics conduct research and publish results from such exercise, in terms of quality, quantity, and visibility of their publications within a period of time is generally referred to as research productivity $[3,4]$.

\footnotetext{
*Corresponding author: Ugochi Chinonyerem Mbachu; E-mail: uc.mbachu@unizik.edu.ng

Department of Educational Management and Policy, Nnamdi Azikiwe University Awka, Nigeria. 
The research output of academics affiliated with a given university determines the ranking of the university, the institution's prestige, economic status and competitive standing $[6,7,8,9,10]$. In spite of the importance of research and research productivity, scholars (Bassey, et.al [1]; Yusuf, [11]; Okpe, et.al [5]; Igiri et al. [12]; Uwizeye et al., [13]) have observed that research productivity of academics in developing countries, Nigeria inclusive, is abysmally low. This is evident in the results from various higher educational institutions' ranking bodies, where universities in developing countries recorded very low ranks. Such appraisal and ranking of universities is the world webometric ranking of HEIs, Times Higher Education (THE) ranking, among others.

The 2020 webometric ranking of HEIs revealed that no Nigerian university was listed among the top 1,000 HEIs in the world; no university in South East Nigeria was listed among the top 1,500 HEIs in the world. The ranking also shows that there is great disparity between the ranks of private and public universities in South East geopolitical zone of the country. Nine public universities in the zone ranked higher than the highest ranking private university in the zone. This disparity poses serious concern for universities management, academics, students and prospective students of these universities. Kpolovie and Onoshagbegbe [10] explained that the low ranking of Nigerian universities among world and African universities is suggestive of low research productivity of her academic staff. Anyaogu and Iyabo [14] and Kpolovie and Onoshagbegbe [10] have also explained that ownership and management of these institutions and their academic staff have direct link with the research productivity. Also, several studies such as $[1,15,16]$ have shown that the disciplinary affiliation of the academics influences their research productivity.

Since the appraisal or ranking of these universities is majorly based on research productivity of their academics; and the research productivity of academics is linked with the ownership and management of the universities and their academic staff disciplines, there is therefore need for empirical evaluation and comparison of the research productivity of academics in private and public universities in South East, Nigeria, as well as the significance of the disciplinary affiliation on the research productivity of these academics.

In line with the general objective of the study - to comparatively analyze the research productivity of academics in public and private universities in South East, Nigeria; three research questions and three hypotheses (tested at 0.05 level of significance) were developed for the study.

The research questions;

- What are the research productivity scores of academics in private and public universities in South East, Nigeria?

- What are the research productivity scores of academics in science based disciplines in private and public universities in South East, Nigeria?

- What are the research productivity scores of academics in humanities based disciplines in private and public universities in South East, Nigeria?

The hypotheses;

- There is no significant difference in the mean research productivity scores of academics in private and public universities in South East, Nigeria.

- There is no significant difference in the mean research productivity scores of science based academics in private and public universities in South East, Nigeria.

- There is no significant difference in the mean research productivity scores of humanities based academics in private and public universities in South East, Nigeria.

\section{Research Methodology}

Ex-post-facto research design was adopted for the study. This study was conducted in the South East geopolitical zone of Nigeria. There are five states in the zone with 23 universities (11 public and 12 private). A sample size of 1,119 academics (896 from public and 223 from private universities) drawn from a population of 10,946 academics (9,184 from public universities and 1,762 from private universities) was used for the study. The multi-stage sampling procedure which involved simple random sampling, proportionate and disproportionate stratified random sampling technique was used to derive the sample size. At the first stage, simple random sampling was used to sample two states (Anambra and Enugu states) out of the five states in South East, Nigeria. Then, the universities were stratified on the basis of type, namely: public and private universities. Two public and two private universities were randomly drawn using simple random sampling from each of the sampled states, giving a total of eight universities; four public and four 
private. The public universities sampled are: Nnamdi Azikiwe University and Chukwuemeka Odumegwu Ojukwu University for Anambra state; and University of Nigeria, Nsukka and Enugu State University, for Enugu state. The private universities sampled include: Madonna University and Paul University for Anambra state; and Godfrey Okoye University and Caritas University for Enugu state. The next stage involved sampling of the 1,119 academics from the eight universities already sampled. This was done using proportionate stratified sampling technique to draw $20 \%$ of staff from each of the eight universities sampled. This resulted to 244, 94, 414, 144, 101, 26, 54 and 42 for the eight universities respectively. Disproportionate stratified sampling technique was used to distribute $50 \%$ each for science based and humanities based disciplines in the sampled universities.

Data were collected using a researcher developed instrument titled Academic Staff Research Productivity Questionnaire (ASRPQ) from 2016/2017 to 2018/2019 academic sessions. The period of three academic sessions is chosen because, although academics in Nigerian universities are appraised yearly, these academics are usually due for promotion to higher ranks after a minimum of three academic sessions (years) on the current rank. Their performance in the three academic sessions (years) is therefore important in the appraisal and promotion exercise. The instrument covered nine forms of research output in two dimensions of local and international. The forms are textbooks, book chapters, journal articles, monographs, occasional papers, conference proceedings, patent and certified inventions, technical reports and scientific and peer-reviewed bulletins. An academic staff was required to indicate the number of single or co-authored works he/she has published under the identified forms of research output. All the items of ASRPQ are structured on a five point scale of None, 1-2, 3-4, 5-6, and 7 and above (the scale served as the number of research outputs), and weighted $0,1,2,3$ and 4 respectively. The instrument was validated by three experts who are lecturers (one in measurement and evaluation and two in educational management) all in the Faculty of Education NnamdiAzikiwe University, Awka. The reliability of the instrument was ascertained using Cronbach Alpha. This yielded a coefficient of 0.732 for ASRPQ.

Both manual and Computer-Assisted Personal Interviewing (CAPI) system (Google form) were used to collect the required data from academics. The link for the Google form (https://forms.gle/Rb7cLV7PJEaKd2NVA) was sent to either WhatsApp numbers or e-mail addresses of academics in the sampled universities. Out of the 1,119 copies of questionnaire administered, 1,108 copies of questionnaire representing $99.02 \%$ (filled by 888 public university academics and 220 private university academics) were successfully retrieved and used for data analysis.

Mean scores of the responses were used to answer the research questions while t-test was used to test the hypotheses at 0.05 level of significance. For the research questions, where the mean score is 2.00 and above (three and above research output), the item was acceptable, while an item with less than 2.00 which translates to less than three research output, the item was unacceptable. For the testing of hypotheses, where the probability level is less than the significant level of $0.05(\mathrm{p}<0.05)$, the null hypothesis was not accepted, and if the probability level is greater than the significant level of 0.05 , the null hypotheses was accepted. All analysis were done using version 20 of the Statistical Package for Social Sciences (SPSS).

\section{Results and Analysis}

The data collected were analyzed and the results presented in Tables according to the Research Questions and Hypotheses.

Research Question 1: What are the research productivity scores of academics in public and private universities in South East, Nigeria?

Results on Table 1 reveal that out of 18 items representing the various forms of research output (nine local and nine international), none of the items exceeded the mean cut-off score of 2.00 (i.e. 3 and above research publications) for both public and private universities. This implies that on the average, within the three academic sessions $(2016 / 2017$ to 2018/2019) under study, public and private university academics in the region appears not to be productive in any form of the itemized research output. Academics from both public and private university were however found to have highest research output score in international journals $(\bar{x}=1.63, \mathrm{SD}=1.450$ and $\bar{x}=1.16, \mathrm{SD}=1.287$ respectively), and least score in patents and certified inventions $(\bar{x}=0.01, \mathrm{SD}=0.106$ and $\bar{x}=0.00, \mathrm{SD}=0.000$ respectively).

Further analysis reveal that public university's academics scored higher than private university's academics in 12 items (three local and nine international forms of research output) namely: international textbooks, international book chapters, local and international journals, local and international monographs, international occasional papers, local and international conference proceedings, international patents, international technical report and international scientific peer reviewed bulletins. While private university's academics scored higher than their counterparts from 
public university in five items (all local forms of research output) namely: local textbooks, local book chapters, local occasional papers, local technical reports and local scientific peer reviewed bulletins. Both public and private universities had same score for one item - local patent and certified invention.

Table 1 Mean research productivity scores of academics in public and private universities in South East, Nigeria

\begin{tabular}{|c|c|c|c|c|c|c|c|c|}
\hline \multirow[t]{2}{*}{ s/no } & \multirow{2}{*}{\multicolumn{2}{|c|}{ Research Output/Publication }} & \multicolumn{3}{|c|}{$\begin{array}{c}\text { Public University } \\
(\mathrm{N}=\mathbf{8 8 8})\end{array}$} & \multicolumn{3}{|c|}{$\begin{array}{c}\text { Private University } \\
(\mathrm{N}=\mathbf{2 2 0})\end{array}$} \\
\hline & & & Mean & SD & Decision & Mean & SD & Decision \\
\hline \multirow{2}{*}{1} & \multirow{2}{*}{ Text books } & Local & 0.31 & 0.576 & Not accepted & 0.36 & 0.567 & Not accepted \\
\hline & & International & 0.11 & 0.366 & Not accepted & 0.04 & 0.188 & Not accepted \\
\hline \multirow{2}{*}{2} & \multirow{2}{*}{ Book chapters } & Local & 0.45 & 0.752 & Not accepted & 0.50 & 0.797 & Not accepted \\
\hline & & International & 0.20 & 0.539 & Not accepted & 0.17 & 0.530 & Not accepted \\
\hline \multirow{2}{*}{3} & \multirow{2}{*}{$\begin{array}{l}\text { Publication in } \\
\text { journals }\end{array}$} & Local & 1.29 & 1.438 & Not accepted & 0.88 & 1.092 & Not accepted \\
\hline & & International & 1.63 & 1.450 & Not accepted & 1.16 & 1.287 & Not accepted \\
\hline \multirow{2}{*}{4} & \multirow{2}{*}{ Monographs } & Local & 0.25 & 0.815 & Not accepted & 0.24 & 0.539 & Not accepted \\
\hline & & International & 0.63 & 0.337 & Not accepted & 0.04 & 0.188 & Not accepted \\
\hline \multirow{2}{*}{5} & \multirow{2}{*}{ Occasional papers } & Local & 0.30 & 0.806 & Not accepted & 0.43 & 0.764 & Not accepted \\
\hline & & Interna & 0.19 & 0.726 & Not accepted & 0.04 & 0.231 & Not accepted \\
\hline \multirow{2}{*}{6} & \multirow{2}{*}{$\begin{array}{l}\text { Conference } \\
\text { proceedings }\end{array}$} & Local & 1.09 & 1.222 & Not accepted & 0.81 & 0.898 & Not accepted \\
\hline & & International & 0.70 & 1.105 & Not accepted & 0.36 & 0.755 & Not accepted \\
\hline \multirow{2}{*}{7} & \multirow{2}{*}{$\begin{array}{ll}\begin{array}{l}\text { Patent } \\
\text { certified } \\
\text { invention }\end{array} & \\
\end{array}$} & Local & 0.01 & 0.100 & Not accepted & 0.01 & 0.095 & Not accepted \\
\hline & & International & 0.01 & 0.106 & Not accepted & 0.00 & 0.000 & Not accepted \\
\hline \multirow{2}{*}{8} & \multirow{2}{*}{ Technical reports } & Local & 0.22 & 0.587 & Not accepted & 0.32 & 0.612 & Not accepted \\
\hline & & International & 0.12 & 0.518 & Not accepted & 0.08 & 0.361 & Not accepted \\
\hline \multirow{2}{*}{9} & \multirow{2}{*}{$\begin{array}{l}\text { Scientific peer- } \\
\text { reviewed } \\
\text { bulletins }\end{array}$} & Local & 0.12 & 0.488 & Not accepted & 0.20 & 0.461 & Not accepted \\
\hline & & International & 0.11 & 0.395 & Not accepted & 0.06 & 0.280 & Not accepted \\
\hline
\end{tabular}

Research Question 2:What are the research productivity scores of academics in science based disciplines in public and private universities in South East, Nigeria?

Table 2 Mean research productivity scores of academics in science-based disciplines in public and private universities

\begin{tabular}{|c|c|c|c|c|c|c|c|c|}
\hline \multirow[t]{2}{*}{ s/no } & \multirow{2}{*}{\multicolumn{2}{|c|}{ Research Output/Publication }} & \multicolumn{3}{|c|}{$\begin{array}{l}\text { Public University } \\
\text { (N=445) }\end{array}$} & \multicolumn{3}{|c|}{$\begin{array}{c}\text { Private University } \\
(\mathrm{N}=109)\end{array}$} \\
\hline & & & Mean & SD & Decision & Mean & SD & Decision \\
\hline \multirow{2}{*}{1} & \multirow{2}{*}{ Text books } & Local & 0.26 & 0.585 & Not accepted & 0.23 & 0.538 & Not accepted \\
\hline & & International & 0.06 & 0.290 & Not accepted & 0.03 & 0.164 & Not accepted \\
\hline \multirow{2}{*}{2} & \multirow{2}{*}{ Book chapters } & Local & 0.33 & 0.638 & Not accepted & 0.20 & 0.447 & Not accepted \\
\hline & & International & 0.20 & 0.484 & Not accepted & 0.02 & 0.135 & Not accepted \\
\hline \multirow{2}{*}{3} & \multirow{2}{*}{$\begin{array}{l}\text { Publication in } \\
\text { journals }\end{array}$} & Local & 1.29 & 1.372 & Not accepted & 0.61 & 0.953 & Not accepted \\
\hline & & International & 1.63 & 1.411 & Not accepted & 1.19 & 1.371 & Not accepted \\
\hline \multirow{2}{*}{4} & \multirow{2}{*}{ Monographs } & Local & 0.17 & 0.665 & Not accepted & 0.17 & 0.506 & Not accepted \\
\hline & & International & 0.02 & 0.125 & Not accepted & 0.02 & 0.135 & Not accepted \\
\hline \multirow{2}{*}{5} & \multirow{2}{*}{ Occasional papers } & Local & 0.39 & 0.954 & Not accepted & 0.41 & 0.808 & Not accepted \\
\hline & & International & 0.14 & 0.572 & Not accepted & 0.04 & 0.270 & Not accepted \\
\hline
\end{tabular}




\begin{tabular}{|c|l|l|l|l|l|l|c|c|}
\hline \multirow{2}{*}{6} & \multirow{2}{*}{$\begin{array}{l}\text { fonference } \\
\text { proceedings }\end{array}$} & Local & 1.18 & 1.203 & Not accepted & 0.65 & 0.875 & Not accepted \\
\cline { 3 - 9 } & International & 0.65 & 0.971 & Not accepted & 0.38 & 0.791 & Not accepted \\
\hline \multirow{2}{*}{7} & \multirow{2}{*}{$\begin{array}{l}\text { Patent and } \\
\text { certified invention }\end{array}$} & Local & 0.02 & 0.133 & Not accepted & 0.02 & 0.135 & Not accepted \\
\cline { 3 - 9 } & International & 0.02 & 0.125 & Not accepted & 0.00 & 0.000 & Not accepted \\
\hline \multirow{2}{*}{8} & \multirow{2}{*}{ Technical reports } & Local & 0.37 & 0.726 & Not accepted & 0.40 & 0.639 & Not accepted \\
\cline { 3 - 9 } & & International & 0.18 & 0.628 & Not accepted & 0.14 & 0.481 & Not accepted \\
\hline \multirow{2}{*}{9} & \multirow{2}{*}{$\begin{array}{l}\text { Scientific peer- } \\
\text { reviewed bulletins }\end{array}$} & Local & 0.15 & 0.510 & Not accepted & 0.21 & 0.410 & Not accepted \\
\cline { 2 - 9 } & International & 0.16 & 0.398 & Not accepted & 0.09 & 0.290 & Not accepted \\
\hline
\end{tabular}

Results on Table 2 reveal that out of 18 items representing the various forms of research output (nine local and nine international forms), none of the items had mean scores up to the cut-off mean score of 2.00 for science-based academics in both public and private universities. The result shows that on the average, within the three academic sessions $2016 / 2017$ to 2018/2019, in all the forms of research output, the research productivity of science-based academics in both public and private universities in the region are not acceptable based on the benchmark. Science-based academics were however found to be most productive in international journals $(\bar{x}=1.63, \mathrm{SD}=1.411$ and $\bar{x}=1.19, \mathrm{SD}=1.371$ for public and private universities respectively). They were least productive in patents and certified inventions $(\bar{x}=0.02$, $\mathrm{SD}=0.125$ and $\bar{x}=0.00, \mathrm{SD}=0.000$ for public and private universities respectively)

Further analysis reveal that public universities science-based academics scored higher than private universities sciencebased academics in 12 items (four local and eight international forms of research output) namely: local and international textbooks, local and international book chapters, local and international journals, international occasional papers, local and conference proceedings, international patents, international technical report and international scientific and peer reviewed bulletins. While private universities science-based academics scored higher than public universities in three items (all local forms of research output) namely: local occasional papers, local technical reports and local scientific peer reviewed bulletins. Both public and private universities had same mean score for three items local monographs 0.17 , international monographs 0.02 , and local patent and certified inventions 0.02 .

From the analysis above, it can be concluded that within the three academic sessions under study, science-based academics in public and private universities had low research productivity being that on the average, academics in both university types did not attain the mean cut-off score in any form of research output. However, science-based academics in public universities were found to be more research productive than private universities academics in most forms of research output.

Research Question 3:What are the research productivity scores of academics in humanities based disciplines in public and private universities in South East, Nigeria?

Table 3 Mean research productivity scores of humanities based academics in public and private universities

\begin{tabular}{|c|c|c|c|c|c|c|c|c|}
\hline \multirow[t]{2}{*}{ s/no } & \multirow{2}{*}{\multicolumn{2}{|c|}{$\begin{array}{c}\text { Research } \\
\text { Output/Publication }\end{array}$}} & \multicolumn{3}{|c|}{$\begin{array}{l}\text { Public University } \\
\qquad(\mathrm{N}=443)\end{array}$} & \multicolumn{3}{|c|}{$\begin{array}{l}\text { Private University } \\
\qquad(\mathrm{N}=111)\end{array}$} \\
\hline & & & Mean & SD & Decision & Mean & SD & Decision \\
\hline \multirow{2}{*}{1} & \multirow{2}{*}{ Text books } & Local & 0.36 & 0.564 & Not accepted & 0.48 & 0.570 & Not accepted \\
\hline & & International & 0.17 & 0.423 & Not accepted & 0.05 & 0.208 & Not accepted \\
\hline \multirow{2}{*}{2} & \multirow{2}{*}{$\begin{array}{l}\text { Book } \\
\text { chapters }\end{array}$} & Local & 0.58 & 0.835 & Not accepted & 0.78 & 0.948 & Not accepted \\
\hline & & International & 0.19 & 0.590 & Not accepted & 0.32 & 0.703 & Not accepted \\
\hline \multirow{2}{*}{3} & \multirow{2}{*}{$\begin{array}{l}\text { Publication } \\
\text { in journals }\end{array}$} & Local & 1.29 & 1.503 & Not accepted & 1.15 & 1.154 & Not accepted \\
\hline & & International & 1.64 & 1.489 & Not accepted & 1.12 & 1.204 & Not accepted \\
\hline & \multirow{2}{*}{ Monographs } & Local & 0.33 & 0.936 & Not accepted & 0.30 & 0.566 & Not accepted \\
\hline & & International & 0.11 & 0.455 & Not accepted & 0.05 & 0.227 & Not accepted \\
\hline
\end{tabular}


World Journal of Advanced Research and Reviews, 2022, 13(01), 565-575

\begin{tabular}{|c|l|l|l|l|l|l|l|l|}
\hline 5 & \multirow{2}{*}{$\begin{array}{l}\text { Occasional } \\
\text { papers }\end{array}$} & Local & 0.20 & 0.609 & Not accepted & 0.44 & 0.722 & Not accepted \\
\cline { 3 - 9 } & International & 0.24 & 0.850 & Not accepted & 0.04 & 0.187 & Not accepted \\
\hline \multirow{2}{*}{6} & $\begin{array}{l}\text { Conference } \\
\text { proceedings }\end{array}$ & Local & 0.99 & 1.235 & Not accepted & 0.96 & 0.898 & Not accepted \\
\cline { 3 - 9 } & International & 0.74 & 1.225 & Not accepted & 0.35 & 0.722 & Not accepted \\
\hline 7 & $\begin{array}{l}\text { Patent and } \\
\text { certified } \\
\text { invention }\end{array}$ & Local & 0.00 & 0.048 & Not accepted & 0.00 & 0.00 & Not accepted \\
\cline { 3 - 9 } & International & 0.01 & 0.082 & Not accepted & 0.00 & 0.00 & Not accepted \\
\hline 8 & $\begin{array}{l}\text { Technical } \\
\text { reports }\end{array}$ & Local & 0.07 & 0.342 & Not accepted & 0.25 & 0.580 & Not accepted \\
\cline { 3 - 10 } & International & 0.05 & 0.368 & Not accepted & 0.03 & 0.163 & Not accepted \\
\hline 9 & $\begin{array}{l}\text { Scientific } \\
\text { peer- } \\
\text { reviewed } \\
\text { bulletins }\end{array}$ & Local & 0.08 & 0.462 & Not accepted & 0.18 & 0.508 & Not accepted \\
\cline { 3 - 9 } & International & 0.06 & 0.387 & Not accepted & 0.04 & 0.267 & Not accepted \\
\hline
\end{tabular}

Results on Table 3 reveal that out of 18 items representing the various forms of research output (nine local and nine international forms), none of the items recorded up to the cut-off mean score of 2.00 for humanities based academics in both public and private universities. This implies that on the average, within the three academic sessions 2016/2017 to $2018 / 2019$, humanities based academics in both types of university were not productive in any form of itemized research output. Humanities based academics were however found to be most productive in international journals $(\bar{x}=$ 1.64, $\mathrm{SD}=1.489)$ and local journals $(\bar{x}=1.15, \mathrm{SD}=1.154)$ for public and private universities respectively. They were also found to be least productive in patents and certified inventions, $(\bar{x}=0.00, \mathrm{SD}=0.048 ; \bar{x}=0.00, \mathrm{SD}=0.000$ for public and private universities respectively).

Further probe into the result shows that humanities based academics in public universities scored higher than those in private universities in 11 items (three local and eight international forms of research output) namely: international textbooks, local and international journals, local and international monographs, international occasional papers, local and international conference proceedings, international patents and certified inventions, international technical report and international scientific and peer reviewed bulletins. The humanities based academics in private universities scored higher than their counterparts in public universities in six items (five local and one international forms of research output) namely: local textbooks, local and international book chapters, local occasional papers, local technical reports and local scientific peer reviewed bulletins. Both public and private universities had same score 0.00 for one item - local patent and certified invention.

From the analysis above, it can be concluded that within the three academic sessions, humanities based academics in public and private universities had low research productivity being that on the average, the academics in both university types did not attain the cut-off mean score in any form of research output. However, public universities humanities based academics were found to be more research productive than private universities humanities based academics, having scored higher in 11 items, while their counterparts scored higher only in six items.

Hypothesis 1: There is no significant difference in the mean research productivity scores of academics in public and private universities in South East, Nigeria.

Table 4 displays the t-test comparison of the mean research productivity scores of public and private university academics. Results on the said table reveal that there is no statistically significant difference between the mean research productivity scores of academics in public and private universities in seven forms of research output (four local and three international) which had their probability values greater than the level of significance 0.05 . These are namely: local textbooks, local book chapters, international book chapters, local monographs, international monographs, local patents and certified inventions and international technical reports. Thus the null hypotheses for these items were accepted.

The results further reveal that there exists statistically significant difference between the mean research productivity scores of the two groups of academics in 11 forms of research output (five local and six international forms) which had their probability values less than the 0.05 level of significance. These are namely: international textbooks, local and 
international journals, local and international occasional papers, local and international conference proceedings, international patents and certified inventions, local technical report, local and international scientific peer-reviewed bulletins. Thus the null hypotheses for these items were not accepted.

Table 4 T-test comparison of mean research productivity scores of academics in public and private universities in South East, Nigeria

\begin{tabular}{|c|c|c|c|c|c|c|c|c|c|c|}
\hline \multicolumn{11}{|c|}{ *S - Significant, NS - Not Significant } \\
\hline \multirow[t]{2}{*}{ s/no } & \multirow{2}{*}{\multicolumn{2}{|c|}{ Research Output/Publication }} & \multicolumn{2}{|c|}{$\begin{array}{c}\text { Public } \\
\text { University } \\
(\mathrm{N}=\mathbf{8 8 8})\end{array}$} & \multicolumn{2}{|c|}{$\begin{array}{c}\text { Private } \\
\text { University } \\
(\mathrm{N}=220)\end{array}$} & \multirow{3}{*}{$\begin{array}{c}\begin{array}{c}\text { t- } \\
\text { value }\end{array} \\
-0.985\end{array}$} & \multirow{3}{*}{$\begin{array}{c}\mathbf{d f} \\
1106\end{array}$} & \multirow{3}{*}{$\begin{array}{c}\begin{array}{c}\text { Sig } \\
\text { (2- } \\
\text { tail) } \\
\text { (p } \\
\text { value) }\end{array} \\
0.325\end{array}$} & \multirow{3}{*}{$\begin{array}{c}\text { Remark } \\
\text { NS }\end{array}$} \\
\hline & & & Mean & SD & Mean & SD & & & & \\
\hline \multirow{2}{*}{1} & \multirow{2}{*}{ Text books } & Local & 0.31 & 0.576 & 0.36 & 0.567 & & & & \\
\hline & & International & 0.11 & 0.366 & 0.04 & 0.188 & 4.325 & 677.561 & 0.000 & S \\
\hline \multirow{2}{*}{2} & \multirow{2}{*}{ Book chapters } & Local & 0.45 & 0.752 & 0.50 & 0.797 & -0.726 & 1106 & 0.468 & NS \\
\hline & & International & 0.20 & 0.539 & 0.17 & 0.530 & 0.574 & 1106 & 0.566 & NS \\
\hline \multirow{2}{*}{3} & \multirow{2}{*}{$\begin{array}{l}\text { Publication in } \\
\text { journals }\end{array}$} & Local & 1.29 & 1.438 & 0.88 & 1.092 & 4.606 & 428.225 & 0.000 & S \\
\hline & & International & 1.63 & 1.450 & 1.16 & 1.287 & 4.797 & 369.351 & 0.000 & $\mathrm{~S}$ \\
\hline \multirow{2}{*}{4} & \multirow{2}{*}{ Monographs } & Local & 0.25 & 0.815 & 0.24 & 0.539 & 0.177 & 1106 & 0.859 & NS \\
\hline & & International & 0.63 & 0.337 & 0.04 & 0.188 & 1.574 & 611.407 & 0.116 & NS \\
\hline \multirow{2}{*}{5} & \multirow{2}{*}{$\begin{array}{l}\text { Occasional } \\
\text { papers }\end{array}$} & Local & 0.30 & 0.806 & 0.43 & 0.764 & -2.273 & 349.961 & 0.024 & $S$ \\
\hline & & International & 0.19 & 0.726 & 0.04 & 0.231 & 5.362 & 1049.44 & 0.000 & $\mathrm{~S}$ \\
\hline \multirow{2}{*}{6} & \multirow{2}{*}{$\begin{array}{l}\text { Conference } \\
\text { proceedings }\end{array}$} & Local & 1.09 & 1.222 & 0.81 & 0.898 & 3.828 & 443.047 & 0.000 & $\mathrm{~S}$ \\
\hline & & International & 0.70 & 1.105 & 0.36 & 0.755 & 5.275 & 479.814 & 0.000 & $\mathrm{~S}$ \\
\hline \multirow{2}{*}{7} & \multirow{2}{*}{$\begin{array}{l}\text { Patent and } \\
\text { certified } \\
\text { invention }\end{array}$} & Local & 0.01 & 0.100 & 0.01 & 0.095 & 0.140 & 1106 & 0.889 & NS \\
\hline & & International & 0.01 & 0.106 & 0.00 & 0.000 & 3.178 & 887.000 & 0.002 & $S$ \\
\hline \multirow{2}{*}{8} & \multirow{2}{*}{$\begin{array}{l}\text { Technical } \\
\text { reports }\end{array}$} & Local & 0.22 & 0.587 & 0.32 & 0.612 & -2.206 & 325.816 & 0.028 & $\mathrm{~S}$ \\
\hline & & International & 0.12 & 0.518 & 0.08 & 0.361 & 0.893 & 1106 & 0.372 & NS \\
\hline \multirow{2}{*}{9} & \multirow{2}{*}{$\begin{array}{l}\text { Scientific peer- } \\
\text { reviewed } \\
\text { bulletins }\end{array}$} & Local & 0.12 & 0.488 & 0.20 & 0.461 & -2.261 & 350.521 & 0.024 & S \\
\hline & & International & 0.11 & 0.395 & 0.06 & 0.280 & 1.979 & 461.460 & 0.048 & $\mathrm{~S}$ \\
\hline
\end{tabular}

From the analysis above, it is deduced that while academics in public and private universities did not differ significantly on their mean research productivity scores in seven forms of research output, there was statistically significant differences in their mean scores in 11 forms of research productivity. It was therefore concluded that statistically there is significant difference between the mean research productivity scores of academics in public universities and those in private universities. The null hypothesis is therefore not accepted.

Hypothesis 2: There is no significant difference in the mean research productivity scores of science based academics in public and private universities in South East, Nigeria.

Table 5 t-test comparison of mean research productivity scores of academics in science-based disciplines in public and private universities 


\begin{tabular}{|c|c|c|c|c|c|c|c|c|c|c|}
\hline \multirow[t]{2}{*}{ s/no } & \multirow{2}{*}{\multicolumn{2}{|c|}{$\begin{array}{c}\text { Research } \\
\text { Output/Publication }\end{array}$}} & \multicolumn{2}{|c|}{$\begin{array}{c}\text { Public } \\
\text { University } \\
(\mathrm{N}=445)\end{array}$} & \multicolumn{2}{|c|}{$\begin{array}{c}\text { Private } \\
\text { University } \\
(\mathrm{N}=109)\end{array}$} & \multirow[t]{2}{*}{ t-value } & \multirow[t]{2}{*}{ Df } & \multirow[t]{2}{*}{$\begin{array}{c}\text { Sig } \\
\text { (2-tail) } \\
\text { p value }\end{array}$} & \multirow[t]{2}{*}{ Remark } \\
\hline & & & Mean & SD & Mean & SD & & & & \\
\hline \multirow{2}{*}{1} & \multirow{2}{*}{ Text books } & Local & 0.26 & 0.585 & 0.23 & 0.538 & 0.509 & 552 & 0.611 & NS \\
\hline & & International & 0.06 & 0.290 & 0.03 & 0.164 & 1.586 & 294.047 & 0.114 & NS \\
\hline \multirow{2}{*}{2} & \multirow{2}{*}{$\begin{array}{l}\text { Book } \\
\text { chapters }\end{array}$} & Local & 0.33 & 0.638 & 0.20 & 0.447 & 2.495 & 228.965 & 0.013 & $S$ \\
\hline & & International & 0.20 & 0.484 & 0.02 & 0.135 & 6.99 & 544.891 & 0.000 & $S$ \\
\hline \multirow{2}{*}{3} & \multirow{2}{*}{$\begin{array}{l}\text { Publication in } \\
\text { journals }\end{array}$} & Local & 1.29 & 1.372 & 0.61 & 0.953 & 6.088 & 230.985 & 0.000 & S \\
\hline & & International & 1.63 & 1.411 & 1.19 & 1.371 & 2.881 & 552 & 0.004 & S \\
\hline \multirow{2}{*}{4} & \multirow{2}{*}{ Monographs } & Local & 0.17 & 0.665 & 0.17 & 0.506 & -0.085 & 552 & 0.932 & NS \\
\hline & & International & 0.02 & 0.125 & 0.02 & 0.135 & -0.193 & 552 & 0.847 & NS \\
\hline \multirow{2}{*}{5} & \multirow{2}{*}{$\begin{array}{l}\text { Occasional } \\
\text { papers }\end{array}$} & Local & 0.39 & 0.954 & 0.41 & 0.808 & -0.198 & 552 & 0.843 & NS \\
\hline & & International & 0.14 & 0.572 & 0.04 & 0.270 & 2.74 & 368.537 & 0.006 & S \\
\hline \multirow{2}{*}{6} & \multirow{2}{*}{$\begin{array}{l}\text { Conference } \\
\text { proceedings }\end{array}$} & Local & 1.18 & 1.203 & 0.65 & 0.875 & 5.188 & 219.688 & 0.000 & $S$ \\
\hline & & International & 0.65 & 0.971 & 0.38 & 0.791 & 3.133 & 195.960 & 0.002 & S \\
\hline \multirow{2}{*}{7} & \multirow{2}{*}{$\begin{array}{l}\text { Patent and } \\
\text { certified } \\
\text { invention }\end{array}$} & Local & 0.02 & 0.133 & 0.02 & 0.135 & -0.026 & 552 & 0.979 & NS \\
\hline & & International & 0.02 & 0.125 & 0.00 & 0.000 & 2.664 & 444.000 & 0.008 & S \\
\hline \multirow{2}{*}{8} & \multirow{2}{*}{$\begin{array}{l}\text { Technical } \\
\text { reports }\end{array}$} & Local & 0.37 & 0.726 & 0.40 & 0.639 & -0.313 & 552 & 0.755 & NS \\
\hline & & International & 0.18 & 0.628 & 0.14 & 0.481 & 0.621 & 552 & 0.535 & NS \\
\hline \multirow[b]{2}{*}{9} & \multirow{2}{*}{$\begin{array}{l}\text { Scientific } \\
\text { peer- } \\
\text { reviewed } \\
\text { bulletins }\end{array}$} & Local & 0.15 & 0.510 & 0.21 & 0.410 & -1.106 & 552 & 0.269 & NS \\
\hline & & International & 0.16 & 0.398 & 0.09 & 0.290 & 1.886 & 219.240 & 0.061 & NS \\
\hline
\end{tabular}

Table 5 displays the t-test comparison of the mean research productivity scores of public and private university sciencebased academics. The results reveal that out of the 18 items representing the various forms of research output (nine local and nine international forms), statistically, there was no significant difference between the mean ratings of the two groups of academics for 10 items (six local and four international forms of research output) which have their probability values greater than 0.05 level of significance. These are namely: local and international textbooks, local and international monographs, local occasional papers, local patents and certified inventions, local technical reports and local scientific peer reviewed bulletins. Thus the null hypotheses for these items were accepted. The results further reveal that there is statistically significant difference between the mean scores of science-based academics in public and private universities in the remaining eight items (three local and five international forms of research output) which had their probability values less than the level of significance 0.05 . These are namely: local and international book chapters, local and international journals, international occasional papers, local and international conference proceedings and international patent and certified inventions. Thus the null hypotheses for these items were not accepted.

Further analysis reveal that while the mean ratings of science-based academics in public and private universities was not significant in 10 out of the 18 forms of research output listed, it was significant in the remaining eight out of the 18 items. It is therefore concluded that the mean research productivity scores of science-based academics in private and public universities do not significantly differ. The second null hypothesis is therefore accepted.

Hypothesis 3: There is no significant difference in the mean research productivity scores of humanities based academics in public and private universities in South East, Nigeria. 
Table 6 t-test comparison of mean research productivity scores of academics in humanities based disciplines in public and private universities

\begin{tabular}{|c|c|c|c|c|c|c|c|c|c|c|}
\hline \multicolumn{11}{|c|}{${ }^{*}$ S - Significant, NS - Not Significant } \\
\hline \multirow[t]{2}{*}{ s/no } & \multirow{2}{*}{\multicolumn{2}{|c|}{$\begin{array}{c}\text { Research } \\
\text { Output/Publication }\end{array}$}} & \multicolumn{2}{|c|}{$\begin{array}{c}\text { Public } \\
\text { University } \\
(\mathrm{N}=443)\end{array}$} & \multicolumn{2}{|c|}{$\begin{array}{c}\text { Private } \\
\text { University } \\
(\mathrm{N}=111)\end{array}$} & \multirow{3}{*}{$\begin{array}{c}\begin{array}{c}\mathbf{t}- \\
\text { value }\end{array} \\
-1.902\end{array}$} & \multirow{3}{*}{$\begin{array}{l}\text { Df } \\
552\end{array}$} & \multirow{3}{*}{$\begin{array}{c}\text { Sig } \\
(2- \\
\text { tail) } \\
\mathbf{p} \\
\text { value } \\
0.058\end{array}$} & \multirow{3}{*}{$\begin{array}{c}\text { Remark } \\
\text { NS }\end{array}$} \\
\hline & & & Mean & SD & Mean & CD & & & & \\
\hline \multirow{2}{*}{1} & \multirow{2}{*}{ Text books } & Local & 0.36 & 0.564 & 0.48 & 0.570 & & & & \\
\hline & & international & 0.17 & 0.423 & 0.05 & 0.208 & 4.248 & 358.894 & 0.000 & S \\
\hline \multirow{2}{*}{2} & \multirow{2}{*}{$\begin{array}{l}\text { Book } \\
\text { chapters }\end{array}$} & Local & 0.58 & 0.835 & 0.78 & 0.948 & -2.117 & 155.490 & 0.036 & S \\
\hline & & international & 0.19 & 0.590 & 0.32 & 0.703 & -1.862 & 151.172 & 0.065 & NS \\
\hline \multirow{2}{*}{3} & \multirow{2}{*}{$\begin{array}{l}\text { Publication } \\
\text { in journals }\end{array}$} & Local & 1.29 & 1.503 & 1.15 & 1.154 & 1.021 & 213.850 & 0.308 & NS \\
\hline & & international & 1.64 & 1.489 & 1.12 & 1.204 & 3.881 & 203.056 & 0.000 & S \\
\hline \multirow{2}{*}{4} & \multirow{2}{*}{ Monographs } & Local & 0.33 & 0.936 & 0.30 & 0.566 & 0.299 & 552 & 0.765 & NS \\
\hline & & international & 0.11 & 0.455 & 0.05 & 0.227 & 1.852 & 353.625 & 0.065 & NS \\
\hline \multirow{2}{*}{5} & \multirow{2}{*}{$\begin{array}{l}\text { Occasional } \\
\text { papers }\end{array}$} & Local & 0.20 & 0.609 & 0.44 & 0.722 & -3.294 & 151.492 & 0.001 & $\mathrm{~S}$ \\
\hline & & international & 0.24 & 0.850 & 0.04 & 0.187 & 4.707 & 547.255 & 0.000 & S \\
\hline \multirow{2}{*}{6} & \multirow{2}{*}{$\begin{array}{l}\text { Conference } \\
\text { proceedings }\end{array}$} & Local & 0.99 & 1.235 & 0.96 & 0.898 & 0.348 & 226.187 & 0.728 & NS \\
\hline & & international & 0.74 & 1.225 & 0.35 & 0.722 & 4.303 & 288.782 & 0.000 & $S$ \\
\hline \multirow{2}{*}{7} & \multirow{2}{*}{$\begin{array}{l}\text { Patent and } \\
\text { certified } \\
\text { invention }\end{array}$} & Local & 0.00 & 0.048 & 0.00 & 0.00 & 0.50 & 552 & 0.617 & NS \\
\hline & & international & 0.01 & 0.082 & 0.00 & 0.00 & 0.868 & 552 & 0.386 & NS \\
\hline \multirow{2}{*}{8} & \multirow{2}{*}{$\begin{array}{l}\text { Technical } \\
\text { reports }\end{array}$} & Local & 0.07 & 0.342 & 0.25 & 0.580 & -3.139 & 129.789 & 0.002 & S \\
\hline & & international & 0.05 & 0.368 & 0.03 & 0.163 & 0.696 & 552 & 0.487 & NS \\
\hline \multirow[b]{2}{*}{9} & \multirow{2}{*}{$\begin{array}{l}\text { Scientific } \\
\text { peer- } \\
\text { reviewed } \\
\text { bulletins }\end{array}$} & Local & 0.08 & 0.462 & 0.18 & 0.508 & -1.91 & 158.547 & 0.058 & NS \\
\hline & & international & 0.06 & 0.387 & 0.04 & 0.267 & 0.699 & 552 & 0.485 & NS \\
\hline
\end{tabular}

Table 6 displays the t-test comparison of the mean research productivity scores of public and private university humanities based academics. The results reveal that out of the 18 items representing the various forms of research output (nine local and nine international forms), there was no statistically significant difference between the two groups of academics for 11 items (six local and five international forms of research output) which had their probability values greater than the 0.05 level of significance. These were namely: local textbooks, international book chapters, local journals, local and international monographs, local conference proceedings, local and international patents and certified inventions, international technical reports and local and international scientific peer reviewed bulletins. Thus the null hypotheses for these items were accepted. The results further reveal that there is significant difference between the mean scores of humanities based academics in public and private universities in seven items (three local and four international forms of research output) which had their probability values less than the 0.05 level of significance. These are namely: international textbooks, local book chapters, international journals, local and international occasional papers, international conference proceedings and local technical reports. Thus the null hypotheses for these items were not accepted.

The analysis above reveal that while the mean rating of humanities based academics in public and private universities were not significant in 11 out of the 18 forms of research output listed, it was significant in the remaining seven out of 
18 items listed. It is therefore concluded that the mean research productivity scores of humanities based academics in private and public universities are not significantly different. The third null hypothesis is therefore accepted.

\section{Discussion of Findings}

From the above analysis, it can be concluded that within the three academic sessions under review, the academics in both public and private universities in the region had low research productivity, having not attain the mean cut-off score in any form of research output. This finding is in agreement with the findings of $[6,2,17,10,13]$. Private universities were however found to have significantly lower research productivity than public universities. This may be a plausible reason for the low ranking and wide disparities in ranks between public and private universities in South East, Nigeria. Be that as it may, findings showed that science and humanities based academics in public universities both scored higher than their counterparts in private universities.

With respect to the various forms of research output, findings revealed that research productivity of academics was highest in published journals articles and lowest in the production of patents and certified inventions. This agrees with the findings of Okiki [4] who discovered that the research productivity of academics in Nigerian federal universities was mostly in the area of journal publications and the least in patents and certified inventions. With respect to private universities, the findings supported that of Okpe et al. [5], whose study revealed that research output of academics in Nigerian private universities were mostly in the publication of journal articles. Aside the publications in international journals, it was discovered that in most of the other forms of research output, academics published their research works mostly in local forms of research output. This underscores the need for encouragement of academics in South East private and public universities to engage in publishing more of their research output in international platforms for wider visibility and to gain recognition in both local and international academic circles.

Furthermore, with respect to the tested hypotheses, findings revealed a significant difference in the research productivity of academics in public and private universities. This finding agrees with Gadhoum and Karam [18] and Can et al. [19], which submitted that academics in public university are significantly more productive in research than those in private university. But with respect to academic disciplines, in most forms of research output, there was no significant difference between the research productivity of science based academics in private and public universities. Also, in most forms of research outputs, there were no significant difference between the research productivity of humanities based academics in private and public universities. Since there is significant difference in the mean scores of research outputs of academics of private and public universities in international journals, which happens to be the most form of outputs for both university types, it may be right to consider this as one likely reason for such disparity in the ranking of the two university types in South East, Nigeria.

\section{Conclusion}

Undoubtedly, the significant role of research productivity in the ranking of universities cannot be downplayed. The wide disparity in the ranking of private and public universities in South East, Nigeria, gave rise to the comparative analysis of research productivity of academics in public and private universities in South East, Nigeria. Considering the findings of this study which showed that research productivity of academics in public and private universities within year 2016/2017-2018/2019 academic sessions was low, although the academics in the public universities were significantly more productive in research than their counterpart in the private universities. it's thus important for the owners and management of private and public universities in South East Nigeria to give utmost attention to encourage and support research productivity of academics irrespective of their academic disciplines.

Considering the findings from this study, the following recommendations are made:

- Aside from journal article publications which is the most subscribed form of research output, academics should also be encouraged to explore other forms of research output to increase their research productivity.

- Since most academics subscribe to international journal, editors and publishers of journals, books, monographs, among others domiciled in Nigeria, most of which are categorized as 'local' should upgrade their product by sourcing for contribution and subscription from across the globe and also having editors from other parts of the world. This will increase the visibility and rate of subscription to the journals, books and other publications.

- The outcome of this study shows that academics in this region have very low research productivity in the area of patenting and certified inventions. Hence, a clarion calls to encourage researchers and innovators to produce their innovative ideas and patent their works. 
- $\quad$ Private universities' management should support both their science based and humanities based academic staff in research and publication of their research results. This call is as a result of their lower research productivity in most forms of research output when compared to their counterparts in public universities.

- Similar comparative analysis of research productivity of academics in public and private universities should be carried out in Northern Nigeria, where there is similar challenge of poor ranking.

\section{Compliance with ethical standards}

\section{Acknowledgments}

The authors acknowledge the academics in private and public universities in South East, Nigeria who completed the copies of questionnaire, which was used as data for the study.

\section{Disclosure of conflict of interest}

There is no conflict of interest between the authors.

\section{References}

[1] Bassey U, Akuegwu B, Udida L, Udey FU. Academic staff research productivity: A study of universities in southsouth zone of Nigeria. Educational research and review. 2007; 2(5): 103-108.

[2] Okafor VN. Comparative analysis of research output of federal universities in southern Nigeria. Library and philosophy practice. 2011.

[3] Peretomode VF, Chukwuma RA. Manpower development and lecturers' productivity in tertiary institutions in Nigeria. European scientific journal. 2011; 8(13): 16-28.

[4] Okiki CO. Research productivity of teaching faculty members in Nigerian federal universities: An investigative study. Chinese librarianship: An international electronic journal. 2013; 3: 99-118.

[5] Okpe IJ, Simisaye AO, Otuza CE. Research output and pattern of publication among faculty in Nigerian private universities: Babcock university experience. Journal of information and knowledge management. 2013; 3(9): 6471.

[6] Bako S. University, research and development in Nigeria: Time for a paradigmatic shift. Presented at 11 th General Assembly of CODESRIA on Rethinking African Development: Beyond Impasse: Towards Alternatives, Maputo, Mozambique, 6th-8th December 2005.

[7] Lertputtarak S. An investigation of factors related to research productivity in a public university in Thailand: A case study. (Ph.D. dissertation Victoria University, Melbourne, Australia. 2008.

[8] Sulo I, Kendagor R, Rosger D, Turtoek D, Chelangat S. Factors affecting research productivity in public universities of Kenya: The case of Moi University, Eldoret. Journal on emerging trends, economics and management science. 2012; 3(5): 475 - 484.

[9] Johnson BJ, Louw AH. Building research culture from scratch at a university of technology. Mediterranean journal of social sciences. 2014; 5(1): 151-164.

[10] Kpolovie PJ, Onoshagbegbe ES. Research productivity: H-index and i10-index of academics in Nigerian universities. International journal of quantitative and qualitative research method. 2017; 5(2): 62-123.

[11] Yusuf AK. An appraisal of research in Nigeria's university sector. Journal of research in national development. 2012; 10(2): 321-330.

[12] Igiri BE, Okoduwa SIR, Akabuogu EP, Okoduwa UJ, Enang IA, Idowu 00, Onyemachi DI. Focused research on the challenges and productivity of researchers in nigerian academic institutions without funding. Frontiers in research metrics and analytics. 2021; 6: 727228.

[13] Uwizeye D, Karimi F, Thiong'o C, Syonguvi J, Ochieng V, Kiroro F, Wao H. Factors associated with research productivity in higher education institutions in Africa: A systematic review. AAS Open Research. 2021; 4(26): 122.

[14] Anyaogu U, Iyabo M. Demographic variables as correlates of lecturers research productivity in faculties of law in Nigerian universities. DESIDOC Journal of library and information technology. 2014; 34(6): 505-510. 
[15] Obembe OB. Determinants of scientific productivity among Nigerian University academics. Indian journal of science and technology. 2012; 5(2): 1-10.

[16] Jung J. Faculty research productivity in Hong Kong across academic discipline. Higher education studies. 2012; 2(4): 1-13.

[17] Okiki CO. Information literacy skills as factors influencing research productivity of academic staff in Nigerian federal universities. (Doctoral Pre-field Seminar), University of Ibadan, Department of Library, Archival and Information Studies, University of Ibadan, Nigeria. 2011.

[18] Gadhoum Y, Karam Y. The determinants of research productivity in public versus private Saudi universities. Asia Pacific Journal of Advanced Business and Social Studies. 2016; 2(2): 625-660.

[19] Can N, Tursunbadalov S, Keles I. An assessment of scientific research in Nigerian universities. Journal of Economics and Social Research. 2018; 5(10): 32-38. 